https://helda.helsinki.fi

\title{
Value of WTO Trade Agreements in a New Keynesian Model
}

\section{Ganelli, Giovanni}

2015-02-25

Ganelli , G \& Tervala , J 2015 , ' Value of WTO Trade Agreements in a New Keynesian

Model ' , IMF Working Papers , no. 15/37 .<

http://www.imf.org/external/pubs/ft/wp/2015/wp1537.pdf >

http://hdl.handle.net/10138/155107

acceptedVersion

Downloaded from Helda, University of Helsinki institutional repository.

This is an electronic reprint of the original article.

This reprint may differ from the original in pagination and typographic detail.

Please cite the original version. 
Value of WTO Trade Agreements in a New Keynesian Model

Giovanni Ganelli and Juha Tervala 


\title{
IMF Working Paper
}

Asia and Pacific Department

\section{Value of WTO Trade Agreements in a New Keynesian Model \\ Prepared by Giovanni Ganelli and Juha Tervala}

Authorized for distribution by Odd Per Brekk

February 2015

\section{This Working Paper should not be reported as representing the views of the IMF.} The views expressed in this Working Paper are those of the author(s) and do not necessarily represent those of the IMF or IMF policy. Working Papers describe research in progress by the author(s) and are published to elicit comments and to further debate.

\begin{abstract}
We revisit the question of the quantitative benefits of WTO trade agreements in a setup that is non-standard from the traditional trade policy point of view. We show that in a New Keynesian model, unilateral trade liberalization reduces welfare due to terms-of-trade deterioration, creating an incentive for a trade agreement. For realistic parameter values, the value of an agreement, which cuts tariffs by one percentage point, is $0.5 \%$ to $2 \%$ of consumption, much larger than in trade models. The intuition for this result hinges on some New Keynesian features of our framework, such as imperfect competition and endogenous labor supply.
\end{abstract}

JEL Classification Numbers:F13; F41; E60

Keywords: Tariffs; terms of trade theory; trade agreement; trade liberalization; WTO Author’s E-Mail Address:gganelli@imf.org; juha.tervala@helsinki.fi 


\section{INTRODUCTION}

The World Trade Organization (WTO) is an important international organization. In 1995, the WTO replaced the General Agreement on Tariffs and Trade (GATT), which was founded in 1948. One aim of the WTO is to liberalize international trade on a reciprocal basis. To achieve this aim, the WTO has completed eight rounds of trade negotiations that have substantially lowered tariffs and other trade barriers. Standard economic theory, however, calls for unilateral trade liberalization. Small countries, under perfectly competitive markets, have no incentive to impose tariffs. Countries should therefore unilaterally liberalize international trade, because doing so serves their own interests. This makes reciprocal trade liberalization or trade agreements unnecessary. Consequently, the gains of and reasons for WTO trade agreements have been disputed.

The main theory of the WTO is the terms of trade theory, originally proposed by Johnson (1953-1954) and more recently developed by Bagwell and Staiger (1999). This theory relies on the optimal tariff argument: In a two-country model, a large country has an incentive to improve its terms of trade by imposing a tariff. This tariff is likely to lead to retaliation by the other country. When both countries impose tariffs, no individual country can improve its terms of trade at the expense of its neighbor. Tariffs, however, reduce international trade and output in both countries. The purpose of a trade agreement, based on reciprocal trade liberalization, is to resolve the prisoner's dilemma driven by manipulating the terms of trade. The recent empirical literature (Broda et al. 2008 and Bagwell and Staiger 2011) supports the relevance of the terms of trade theory.

In a seminal work, Eaton and Kortum (2002) developed a new trade theory that incorporates Ricardian trade into a general equilibrium framework. Their multi-country model can be calibrated convincingly, and can consequently quantify the welfare gains of unilateral and multilateral trade liberalization. Eaton and Kortum found that a unilateral tariff removal by the United States reduces welfare in that country, due a deterioration of the terms of trade, while all other countries benefit. They showed that the multilateral elimination of $5 \%$ tariffs improves welfare (in case of immobile labor) by less than $0.5 \%$.

Since the publication of Eaton and Kortum (2002), a strand of the trade literature has focused on quantifying the welfare benefits of trade liberalization. Caliendo and Parro (2015), for example, studied the welfare effects of tariff reductions caused by the North American Free Trade Agreement (NAFTA). They found that NAFTA has increased welfare on average by $0.42 \%$. Ossa (2014) analyzed the welfare effects of WTO trade agreements in a framework that features the terms of trade effect, the production relocation effect and the political economy effects. He calibrated the multi-country model to match the features of seven countries and regions (Brazil, China, the European Union, India, Japan, the United States and the rest of the world). He found 
that the average welfare gain of a WTO trade agreement, which eliminates actual tariffs, is $0.5 \%$.

The main innovation of our paper is to explore the quantitative effects of trade liberalization in a setup that is non-standard from the traditional trade policy point of view. This paper uses a New Keynesian two-country model with a fixed number of imperfectly competitive firms and price rigidities to analyze the consequences of unilateral and multilateral trade liberalization. We use a numerical analysis of the model for symmetric countries, with parameters chosen to reflect existing tariff rates and import-to-GDP ratios in the OECD countries, to derive the main results. ${ }^{1}$

The first result is that a unilateral tariff reduction reduces welfare. Earlier work using similar macro models (Fender and Yip 2000, and Reitz and Slopek 2005) suggests an ambiguous relationship between tariffs and welfare in the long term. We argue that, under plausible parameter combinations of the key parameter values of the models, unilateral trade liberalization is welfare decreasing. This result is important to establish a prisoner's dilemma for tariff setting at the relevant parameter values.

The second main result is that the welfare gains of WTO trade agreements are substantial. Following the method of Schmitt-Grohe and Uribe (2007), we measure the value of a WTO trade agreement as the percentage of consumption that households would be willing to pay for a trade agreement in order to remain as well off with the trade agreement case as without it. Our results shows that for the realistic parameter combinations of the Frisch elasticity of labor supply $^{2}$ and the elasticity of substitution between two goods produced in the same country (within-country substitutability), the discounted present value of the welfare gain of a WTO trade agreement, which cuts tariffs by one percentage point, is as high as $0.5 \%$ to $2 \%$ of initial consumption. In addition, the complete elimination of initial $4 \%$ tariffs would cause even greater welfare gains. Therefore, the welfare effects of multilateral trade liberalization are substantially larger in our New Keynesian model than in the trade models of Eaton and Kortum (2002), Caliendo and Parro (2015) and Ossa (2014). Our results imply that WTO agreements are of high value. The policy implication of this is that completion of the Doha Round should be a high priority.

The paper uses two innovations, relative to the models that have been used in the literature on trade agreements (Eaton and Kortum 2002, Caliendo and Parro 2015 and Ossa 2014), that may explain the huge quantitative difference in the results. The first innovation is to introduce transitional dynamics with the introduction of staggered price setting. We show that the

\footnotetext{
${ }^{1}$ We do not attempt to calculate optimal tariffs. We assume that trade liberalization begins at factual tariff rates.

${ }^{2}$ The Frisch elasticity is the elasticity of labor supply with respect to the wage, holding the marginal utility of wealth constant.
} 
introduction of staggered price setting increases the value of a trade agreement. The intuition is that sticky prices make the real wage temporarily higher, which, given a Frisch elasticity, increases labor supply. This brings the economy temporarily closer to the efficient level of consumption and increases welfare. Staggered price setting, however, cannot account for the differences in the results, because it only slightly increases the value of a trade agreement.

The second and main innovation this paper uses is to alter the underlying steady state of the trade models by introducing endogenous labor supply and a different market structure from the one usually assumed. We show that the presence of imperfect substitutability between goods within the same country is a key determinant of our main results. In the quantitative macroeconomics literature, within-country substitutability is virtually always set between 6 and 20. In the trade models, which have been used in the literature on trade agreements, competition within the industry is perfect, implying very high within-country substitutability. In our macro model, the lower within-country substitutability is, the lower the initial level of output is; the lower the initial level of output is, the more an increase in output and consumption (of given size) increases welfare. Therefore, the gains of trade agreement depend significantly on the degree of within-country substitutability.

The public economics and macroeconomics literature has shown that the consequences of taxation on the magnitude of aggregate labor supply are central to optimal tax policy. Trade models that have been used to quantify the gains of multilateral tariff reductions, however, typically assume that utility depends solely on consumption, making the labor supply decision of households exogenous. We show that the higher the Frisch elasticity of labor supply is, the larger the welfare gains of multilateral trade liberalization. If the Frisch elasticity is high, households respond to a tariff reduction by further increasing their labor supply. This brings consumption and output of an imperfectly competitive economy closer to their efficient levels, thereby increasing welfare.

We show that the combination of elastic labor supply and imperfect competition within the country/industry (i.e., low within-country substitutability) accounts for the huge quantitative difference between our results and those of Eaton and Kortum (2002), Caliendo and Parro (2015) and Ossa (2014). We show that for the realistic parameter combinations of the Frisch elasticity of labor supply and within-country substitutability, the welfare gains of WTO trade agreements are much larger than the new trade models have found. On the other hand, our results are consistent with theirs when we set the parameters of the model to be roughly consistent with their assumptions of exogenous labor supply and perfect competition within industry (i.e., when we assume a very low Frisch elasticity and very high within-country substitutability). 
The rest of the paper is organized as follows: Section 2 introduces the model, Section 3 discusses the parameterization, Section 4 studies the international effects of unilateral trade liberalization, Section 5 analyzes the value of multilateral trade agreements and Section 6 concludes the paper.

\section{THE MODEL}

In this section, we develop a New Keynesian two-country model that incorporates distortionary import tariffs. The model is similar to those presented in Fender and Yip (2000) and Reitz and Slopek (2005). Fender and Yip (2000) analyze the effects of a permanent tariff under flexible prices without current account dynamics. Reitz and Slopek (2005) extend the model of Fender and Yip (2000) by introducing current account adjustments and sticky prices in the form of single-period price rigidities.

The empirical evidence points out that the elasticity of substitution between two goods produced in different countries (cross-country substitutability) is much smaller than the elasticity of substitution between two goods produced in the same country (within-country substitutability). Unlike the previous literature, we assume that cross-country substitutability can differ from within-country substitutability. Another unrealistic assumption in Fender and Yip (2000) and Reitz and Slopek (2005) is that, for countries of equal size, their share of imports relative to output is $50 \%$. To match the empirical observed import-to-output ratio, we assume (exogenous) a home bias in consumption (in addition to an endogenous home bias due to tariffs).

Additional differences relative to the existing literature are that we use Calvo-pricing, loglinearize the model around non-zero tariffs, and consider a tariff reduction. Following the idea of Schmitt-Grohe and Uribe (2007), we measure the welfare benefit as a percentage of consumption that the household is willing to pay for a tariff reduction, while Fender and Yip (2000) and Reitz and Slopek (2005) calculate the percent change in utility. Finally, our main focus is on the quantitative gains of multilateral trade liberalization, whereas the previous literature has focused solely unilateral trade liberalization.

The world economy consists of two countries: home and foreign. Firms and households are indexed by $z \in[0,1]$. A fraction $n(1-n)$ of households and firms are located in the domestic (foreign) country. We assume that the domestic (foreign) country imposes an ad valorem tariff on all foreign (domestically) produced goods. In what follows, we present the equations for the domestic country. Unless explicitly discussed, foreign equations are symmetric to domestic ones. 


\section{A. Households}

All households have identical preferences. The utility function of the representative domestic household is given by

$U_{t}=\sum_{s=t}^{\infty} \beta^{s-t}\left[\log C_{s}+\frac{\chi}{1-\varepsilon}\left(\frac{M_{s}}{P_{s}(\tau)}\right)^{1-\varepsilon}-\frac{\left(l_{s}(z)\right)^{1+1 / v}}{1+1 / v}\right]$

where $0<\beta<1$ is the discount factor, $C_{t}$ is a consumption index, $\chi$ is a positive parameter, $M_{t}$ is nominal money balances, $\varepsilon>0$ is the inverse of the consumption elasticity of money demand, and $P_{s}$ is the price index. The expression $P(\tau)$ denotes the fact that the price index is a function of the tariff $\tau$. The household's labor supply is denoted by $l_{t}(z)$ and the Frisch elasticity of labor supply is $v$. As shown later in this paper, the endogeneity of labor supply is a key feature of the model.

The overall consumption index takes into account the Armington element, in which international trade takes place because goods are differentiated by the country of origin. It is given by

$C_{t}=\left[\kappa^{\frac{1}{\rho}}\left(C_{t}^{h}\right)^{\frac{\rho-1}{\rho}}+(1-\kappa)^{\frac{1}{\rho}}\left(C_{t}^{f}\right)^{\frac{\rho-1}{\rho}}\right]^{\frac{\rho}{\rho-1}}$

where $C_{t}^{h}\left(C_{t}^{f}\right)$ is an index of domestic (foreign) goods and $\rho>0$ is cross-country substitutability. $\kappa \equiv n \alpha(0<\kappa<1)$ denotes the share of domestic goods in the consumption basket; it depends on the relative size of the home country $(n)$ and parameter $\alpha$, which captures the degree of home bias in consumption. Home bias in consumption requires $\alpha>1$. The consumption of domestic and foreign goods $C_{t}^{h}$ and $C_{t}^{f}$ are aggregates of the different brands of domestic and foreign goods:

$$
\begin{aligned}
& C_{t}^{h}=\left[n^{-\frac{1}{\theta}} \int_{0}^{n}\left(c_{t}^{h}(z)\right)^{\frac{\theta-1}{\theta}} d z\right]^{\frac{\theta}{\theta-1}}, \\
& C_{t}^{f}=\left[(1-n)^{-\frac{1}{\theta}} \int_{n}^{1}\left(c_{t}^{f}(z)\right)^{\frac{\theta-1}{\theta}} d z\right]^{\frac{\theta}{\theta-1}},
\end{aligned}
$$

where $c_{t}^{h}(z)\left(c_{t}^{f}(z)\right)$ is the consumption of differentiated domestic (foreign) good $z$ by the representative domestic household, and $\theta>1$ is within-country substitutability. 
The foreign consumption index is

$$
C_{t}^{*}=\left[\kappa^{* \frac{1}{\rho}}\left(C_{t}^{* h}\right)^{\frac{\rho-1}{\rho}}+\left(1-\kappa^{*}\right)^{\frac{1}{\rho}}\left(C_{t}^{* f}\right)^{\frac{\rho-1}{\rho}}\right]^{\frac{\rho}{\rho-1}},
$$

where asterisks indicate consumption by the representative foreign household. $\kappa^{*} \equiv n \alpha^{*}$ $\left(0<\kappa^{*}<1\right)$ denotes the share of domestic goods in the foreign consumption basket, and home bias requires $\alpha^{*}<1$.

We assume that the domestic (foreign) country imposes a tariff on all foreign (domestically) produced goods. Given the consumption indexes (2), (3) and (4), the optimal allocation of consumption between different types of goods is governed by the following demand functions:

$$
\begin{aligned}
& c_{t}^{h}(z)=\left[\frac{p_{t}^{h}(z)}{P_{t}^{h}}\right]^{-\theta}\left[\frac{P_{t}^{h}}{P_{t}(\tau)}\right]^{-\rho} \alpha C_{t}, c_{t}^{f}(z)=\left[\frac{\left(1+\tau_{t}\right) p_{t}^{f}(z)}{P_{t}^{f}(\tau)}\right]^{-\theta}\left[\frac{P_{t}^{f}(\tau)}{P_{t}(\tau)}\right]^{-\rho}\left(\frac{1-\kappa}{1-n}\right) C_{t} \\
& c_{t}^{* h}(z)=\left[\frac{\left(1+\tau_{t}^{*}\right) p_{t}^{* h}(z)}{P_{t}^{* h}(\tau)}\right]^{-\theta}\left[\frac{P_{t}^{* h}(\tau)}{P_{t}^{*}(\tau)}\right]^{-\rho} \alpha^{*} C_{t}^{*}, c_{t}^{* f}(z)=\left[\frac{p_{t}^{* f}(z)}{P_{t}^{* f}}\right]^{-\theta}\left[\frac{P_{t}^{* f}}{P_{t}^{*}(\tau)}\right]^{-\rho}\left(\frac{1-\kappa^{*}}{1-n}\right) C_{t}^{*} .
\end{aligned}
$$

$c_{t}^{* h}(z)\left(c_{t}^{* f}(z)\right)$ denotes the consumption of the differentiated domestic (foreign) good $\mathrm{z}$ by the representative foreign household. The demand functions show that domestic households allocate their total consumption $C_{t}$ between domestic and foreign baskets $C_{t}^{h}$ and, by taking into consideration relative prices (including tariffs), cross-country substitutability, and the degree of home bias. Subsequently, domestic households allocate their consumption of domestic and foreign goods across differentiated brands according to relative prices and within-country substitutability.

The domestic currency price of domestic and foreign goods is denoted by $p_{t}^{h}(z)$ and $p_{t}^{f}(z)$, respectively. $P_{t}^{h}$ and $P_{t}^{f}$ are, respectively, the price indexes that correspond to domestic and foreign aggregate consumption baskets $C_{t}^{h}$ and $C_{t}^{f}$. All of these price indexes are expressed in terms of the local currency. Corresponding foreign currency price indexes are denoted by an asterisk. For instance, $p_{t}^{* h}(z)$ is the foreign currency price of a differentiated domestic brand. $P_{t}^{h}$ and $P_{t}^{f}$ are defined as 


$$
\begin{aligned}
& P_{t}^{h}=\left[n^{-1} \int_{0}^{n}\left(p_{t}^{h}(z)\right)^{1-\theta} d z\right]^{\frac{1}{1-\theta}}, \\
& P_{t}^{f}(\tau)=\left[(1-n)^{-1} \int_{n}^{1}\left(\left(1+\tau_{t}\right) p_{t}^{f}(z)\right)^{1-\theta} d z\right]^{\frac{1}{1-\theta}} .
\end{aligned}
$$

These equations define the overall domestic price index as follows

$$
P_{t}(\tau)=\left[\kappa\left(P_{t}^{h}\right)^{1-\rho}+(1-\kappa)\left(P_{t}^{f}(\tau)\right)^{1-\rho}\right]^{\frac{1}{1-\rho}}
$$

The corresponding foreign indexes are defined in an analogous way. As in Fender and Yip (2000), the law of one price holds for all producer prices. Tariffs, however, imply that the law of one price does not hold for consumer prices.

The budget constraint of the domestic household is given by

$$
M_{t}+\delta_{t} D_{t}=D_{t-1}+M_{t-1}+w_{t} l_{t}(z)-P_{t}(\tau) C_{t}+\pi_{t}+P_{t}(\tau) T_{t}
$$

$D$ is the holding of nominal bonds (denominated in domestic currency), $\delta$ is the price of a bond (the inverse of one plus the nominal interest rate), $w_{t}$ is the nominal wage, $\pi$ is nominal dividends (profits), and $T_{t}$ denotes real transfers from the government. Since the bond is denominated in the domestic currency, the budget constraint of the foreign household is

$$
M_{t}^{*}+\delta_{t} \frac{D_{t}^{*}}{S_{t}}=\frac{D_{t-1}^{*}}{S_{t}}+M_{t-1}^{*}+w_{t}^{*} l_{t}^{*}(z)-P_{t}^{*}\left(\tau^{*}\right) C_{t}^{*}+\pi_{t}^{*}+P_{t}^{*}\left(\tau^{*}\right) T_{t}^{*}
$$

where $S_{t}$ is the nominal exchange rate defined as the price of the foreign currency expressed in the domestic currency. A global asset-market clearing condition requires that $n D_{t}+(1-n) D_{t}^{*}=0$.

Domestic households maximize (1) subject to (8). The first order conditions are

$$
\begin{aligned}
& \delta_{t} P_{t+1}(\tau) C_{t+1}=\beta P_{t}(\tau) C_{t}, \\
& \delta_{t} P_{t+1}^{*}\left(\tau^{*}\right) C_{t+1}^{*} S_{t+1}=\beta P_{t}^{*}\left(\tau^{*}\right) C_{t}^{*} S_{t}, \\
& l_{t}(z)=\left(\frac{w_{t}}{C_{t} P_{t}(\tau)}\right)^{v}
\end{aligned}
$$




$$
\begin{aligned}
& l_{t}^{*}(z)=\left(\frac{w_{t}^{*}}{C_{t}^{*} P_{t}^{*}\left(\tau^{*}\right)}\right)^{v}, \\
& \frac{M_{t}}{P_{t}(\tau)}=\left(\frac{\chi C_{t}}{1-\delta_{t}}\right)^{\frac{1}{\varepsilon}}, \\
& \frac{M_{t}^{*}}{P_{t}^{*}\left(\tau^{*}\right)}=\left(\frac{\chi C_{t}^{*}}{1-\frac{\delta_{t} S_{t+1}}{S_{t}}}\right)^{\frac{1}{\varepsilon}} .
\end{aligned}
$$

Equations (9) and (10) are Euler consumption equations. Equations (11) and (12) govern the optimal labor supply. They show that the labor supply is an increasing function of the real wage and a decreasing function of consumption. In addition, tariffs reduce labor supply through their impact on prices. Equations (13) and (14) show that the demand for money is an increasing function of consumption and a decreasing function of the interest rate.

\section{B. The Government}

We abstract from government spending and assume that the government refunds tariff and seignorage revenues to households in a lump-sum manner. ${ }^{3}$ Taking into account symmetry across households, the government budget constraint in per-capita terms can be expressed as

$$
P_{t}(\tau) T_{t}=\tau_{t} c_{t}^{f}(z) p_{t}^{*}(z) S_{t}+M_{t}-M_{t-1} .
$$

In equation (15), the first term on the right hand side denotes revenue from import tariffs that depend on the tariff rate, consumption of foreign goods by domestic households and their price (in the domestic currency).

Similarly, the foreign tariff revenue $\left(R^{*}\right)$ from import tariffs can be shown to be equal to

$$
R_{t}^{*}=\tau_{t}^{*} c_{t}^{h^{*}}(z) p_{t}(z)\left(1 / S_{t}\right)
$$

The domestic tariff rate follows an AR(1) process

$$
\hat{\tau}_{t}=\varphi \hat{\tau}_{t-1}+\psi_{t},
$$

\footnotetext{
${ }^{3}$ Abstracting from seignorage in practice, however, we keep the money supply constant.
} 
where $\varphi \in[0,1]$ and $\psi_{t}$ is a zero mean white-noise process representing an unexpected change in the tariff tax rate. Percentage changes from the initial steady state (denoted by the subscript zero) are denoted by hats (for example: $\hat{\tau}_{t}=\frac{d \tau_{t}}{d \tau_{0}}$ ). We assume that tariff changes are permanent, so we set the persistency parameter $(\varphi)$ to 1 . The parameter $\psi_{t}$ serves to model policy shifts.

\section{Firms}

\section{Technology and Profits}

All firms produce differentiated goods with a production function

$y_{t}(z)=l_{t}(z)$,

where $y_{t}(z)$ is the output of firm $z$, and $l_{t}(z)$ is the labor input firm $z$ uses.

The domestic firm maximizes its profits

$$
\pi_{t}(z)=p_{t}^{h}(z) y_{t}(z)-w_{t} l_{t}(z)
$$

taking into account the production function (16) and the demand curve for its goods

$$
y_{t}^{d}(z)=\left[\frac{p_{t}^{h}(z)}{P_{t}^{h}}\right]^{-\theta}\left[\frac{P_{t}^{h}}{P_{t}(\tau)}\right]^{-\rho} \kappa C_{t}+\left[\frac{\left(1+\tau_{t}^{*}\right) p_{t}^{h}(z)}{S_{t} P_{t}^{* h}(\tau)}\right]^{-\theta}\left[\frac{S_{t} P_{t}^{* h}(\tau)}{S_{t} P_{t}^{*}(\tau)}\right]^{-\rho}(1-n) \alpha^{*} C_{t}^{*}
$$

Using equations (16) and (18), domestic profits can be expressed as

$$
\begin{aligned}
& \pi_{t}(z)=\left[p_{t}^{h}(z)-w_{t}\right] \times \\
& \left\{\left[\frac{p_{t}^{h}(z)}{P_{t}^{h}}\right]^{-\theta}\left[\frac{P_{t}^{h}}{P_{t}(\tau)}\right]^{-\rho} \kappa C_{t}+\left[\frac{\left(1+\tau_{t}^{*}\right) p_{t}^{h}(z)}{S_{t} P_{t}^{* h}(\tau)}\right]^{-\theta}\left[\frac{S_{t} P_{t}^{* h}(\tau)}{S_{t} P_{t}^{*}(\tau)}\right]^{-\rho}(1-n) \alpha^{*} C_{t}^{*}\right\}
\end{aligned}
$$

The profits of the representative foreign firm can be expressed as

$$
\begin{aligned}
& \pi_{t}^{*}(z)=\left[p_{t}^{* f}(z)-w_{t}^{*}\right] \times \\
& \left\{\left[\frac{\left(1+\tau_{t}\right) p_{t}^{* f}(z)}{P_{t}^{f}(\tau) / S_{t}}\right]^{-\theta}\left[\frac{P_{t}^{f}(\tau) / S_{t}}{P_{t}(\tau) / S_{t}}\right]^{-\rho} \frac{n(1-\kappa)}{1-n} C_{t}+\left[\frac{p_{t}^{* f}(z)}{P_{t}^{* f}}\right]^{-\theta}\left[\frac{P_{t}^{* f}}{P_{t}^{*}(\tau)}\right]^{-\rho}\left(1-k^{*}\right) C_{t}^{*}\right\}
\end{aligned}
$$




\section{Price Setting}

In the absence of price rigidities, the domestic firm would maximize equation (19) with respect to $p_{t}^{h}(z)$. The solution is

$p_{t}^{h}(z)=\frac{\theta}{\theta-1} w_{t}$

Equation (21) shows that, without price rigidities, the price is a constant mark-up, determined by within-country substitutability, over the marginal cost.

Based on the idea of Calvo (1983), we assume that each firm can reset its prices with a probability of $1-\gamma$ in any given period, independently of the time elapsed since the last adjustment and of other firms. The representative domestic firm seeks to maximize

$\max _{p_{t}^{h}(z)} V_{t}(z)=\sum_{s=t}^{\infty} \gamma^{s-t} \zeta_{t, s} \pi_{s}(z)$

where $\zeta_{t, s}$ is the stochastic discount factor between periods $\mathrm{t}$ and $\mathrm{s}$. The result of this maximization problem is

$p_{t}(z)=\left(\frac{\theta}{\theta-1}\right) \frac{\sum_{s=t}^{\infty} \gamma^{s-t} \zeta_{t, s} Q_{s} w_{t}}{\sum_{s=t}^{\infty} \gamma^{s-t} \zeta_{t, s} Q_{s}}$

where $Q_{t}=\left[\frac{1}{P_{t}^{h}}\right]^{-\theta}\left[\frac{P_{t}^{h}}{P_{t}(\tau)}\right]^{-\rho} \kappa C_{t}+\left[\frac{\left(1+\tau_{t}^{*}\right)}{S_{t} P_{t}^{* h}(\tau)}\right]^{-\theta}\left[\frac{S_{t} P_{t}^{* h}(\tau)}{S_{t} P_{t}^{*}(\tau)}\right]^{-\rho}(1-n) \alpha^{*} C_{t}^{*}$.

The log-linear version of equation (22) can be expressed as

$\hat{p}_{t}^{h}(z)=\beta \hat{p}_{t+1}^{h}(z)+(1-\beta \gamma) \hat{w}_{t}$.

Equation (23) shows that the change in the optimal price is a weighted average of the changes in current and future marginal costs. 


\section{The Consolidated Budget Constraint}

The consolidated budget constraint for the domestic economy is derived by substituting equations (15) and (17) into equation (7) and can be expressed as

$$
P_{t} C_{t}=D_{t-1}-\delta_{t} D_{t}+p_{t}^{h}(z) y_{t}(z)
$$

In equation (24), $P_{t}$ is the domestic price index without tariffs. The intuition for the dependence of the consolidated budget constraint on the price without taxes is that tariff revenue is a withincountry transfer. $P_{t}$ is defined as

$$
P_{t}=\left[\kappa\left(P_{t}^{h}\right)^{1-\rho}+(1-\kappa)\left(P_{t}^{f}\right)^{1-\rho}\right]^{1} \frac{1}{1-\rho},
$$

where $P_{t}^{h}$ is identical to equation (5), and $P_{t}^{f}$ is

$$
P_{t}^{f}(\tau)=\left[(1-n)^{-1} \int_{n}^{1}\left(p_{t}^{f}(z)\right)^{1-\theta} d z\right]^{\frac{1}{1-\theta}}
$$

Taking into account the global asset-market-clearing condition, the consolidated budget constraint of the foreign economy, can be expressed as

$$
-\frac{n}{1-n} \delta_{t} \frac{D_{t}}{S_{t}}=-\frac{n}{1-n} \frac{D_{t-1}}{S_{t}}-P_{t}^{*} C_{t}^{*}+p_{t}^{* f}(z) y_{t}^{*}(z) .
$$

In this equation, $P_{t}^{*}$ is the foreign price index without tariffs.

\section{E. The Initial Steady State}

The model is log-linearized around a symmetric steady state where initial net foreign assets are zero $\left(D_{0}=0\right)$. Equation (24) therefore implies that $C_{0}=y_{0}$. Equations (11), (16) and (21) thus imply that the initial level of employment and output is

$l_{0}(z)=y_{0}(z)=\left[\frac{(\theta-1) p_{0}(z)}{\theta P_{0}(\tau)}\right]^{\frac{1}{1+1 / v}}$.

Equation (27) shows that the level of output depends on tariffs and the degree of imperfect competition (within-country substitutability). Tariffs reduce the steady-state level of the labor 
supply through their impact on prices. The higher the degree of imperfect competition, the lower the level of output. Equilibrium is defined as sequences of variables that clear the labor, goods and money markets in each country in each period and satisfy intertemporal budget constraints and pricing rules.

\section{Parameterization}

The countries are assumed to be of equal size, so $n$ is set to 0.5 . We interpret periods as quarters and set the discount factor $\beta$ to 0.99 . The consumption elasticity of money demand $(1 / \varepsilon)$ is set to 1 , a value commonly used in the literature. This value is consistent with the empirical estimates of Mankiw and Summers (1986).

Table 2. Parameterization of the Model

\begin{tabular}{|c|c|c|}
\hline Parameter & $\begin{array}{l}\text { Baseline value [range of } \\
\text { parameters] }\end{array}$ & Description \\
\hline$\beta$ & 0.99 & Discount factor \\
\hline$\varepsilon$ & 1 & $\begin{array}{l}\text { Inverse of the consumption } \\
\text { elasticity of money demand }\end{array}$ \\
\hline$\theta$ & $11[6-100]$ & $\begin{array}{l}\text { Within-country } \\
\text { substitutability }\end{array}$ \\
\hline$\rho$ & $2[0.5-11]$ & $\begin{array}{l}\text { Cross-country } \\
\text { substitutability }\end{array}$ \\
\hline$\gamma$ & $0.75[0-0.75]$ & Calvo parameter \\
\hline$n$ & 0.5 & $\begin{array}{l}\text { Relative size of the domestic } \\
\text { economy }\end{array}$ \\
\hline$\tau$ & $0.04[0.02-0.06]$ & Initial tariff rate \\
\hline$\varphi$ & 1 & $\begin{array}{l}\text { Persistence of a tariff tax } \\
\text { shock }\end{array}$ \\
\hline$\psi$ & -0.25 & Size of a tariff shock \\
\hline$\alpha$ & $1.47[1.37-1.68]$ & Home bias parameter \\
\hline$\alpha^{*}$ & $0.53[0.42-0.63]$ & Home bias parameter \\
\hline$v$ & $1[0.1-2]$ & $\begin{array}{l}\text { Frisch elasticity of labor } \\
\text { supply }\end{array}$ \\
\hline
\end{tabular}

Calvo parameter $(\gamma)$ affects the strength and duration of the expenditure switching effect of a nominal exchange rate change. We therefore set the parameter to match the evidence for the price rigidities of internationally traded goods. Gopinath and Rigobon (2008) find that the tradeweighted median price duration of internationally traded goods is roughly one year. Based on this, we set $\gamma$ to 0.75 . This implies that an average delay of four periods (one year) between price adjustments. 
Based on the estimates of Basu and Fernald (1997), we set within-country substitutability $\theta$ to 11. This implies a $10 \%$ markup over the marginal cost in the steady state (recall equation (21)). This is within the 5 to 20 range typically used in the macro literature. It is worth noting that within-country substitutability affects only the initial steady state and welfare results, not the response of endogenous variables. Equation (27) shows that with low within-country substitutability, the initial level of output and employment would be small. If within-country substitutability is too low, trade liberalization could have unrealistically strong welfare effects. However, our benchmark parameterization also implies that within-country substitutability is lower than the one implicitly assumed in trade models, which assume perfect competition with industry.

The choice of a parameter value for cross-country substitutability deserves a more detailed explanation, because the literature on international economics literature has shown that results can depend on it. In a New Keynesian model, the parameter is potentially even more important, because it influences the strength of the expenditure switching effect.

The empirical literature shows a wide range of estimates for cross-country substitutability. Empirical estimates of it that use macroeconomic data and business-cycles models are typically small; estimates are much higher with microeconomic data and trade models. Bergin (2006), for instance, finds that cross-country substitutability is 1.1, using macroeconomic data and a New Keynesian model. As discussed below, Romalis (2007) finds, using microeconomic data and a trade model, that cross-country substitutability is between 6 and 11 .

Feenstra et al. (2014) find that the median estimates of micro elasticity, elasticity between different import suppliers, are between 3.2 and 4.1, whereas the median estimate of macro elasticity, elasticity between home and imported goods, is roughly one. In addition, crosscountry elasticity varies over time. Hooper et al. (2000) find that the sum of the elasticities for imports and exports is typically less than one in absolute value in the short term, but exceeds one after a while. The sum of the export and import elasticities equals cross-country substitutability in the current framework, as shown by Tille (2001).

The trade policy literature has estimated the impact of tariff reductions on the growth of international trade, providing estimates of long-term cross-country substitutability. Head and Reis (2001) analyze the effects of the 1988 Canada-U.S. Free Trade Agreement on trade volumes and prices. They find that trade liberalization leads to a substantial increase in trade and that cross-country substitutability is between 7 and 11. Romalis (2007) analyzes the effects of NAFTA's and finds that the mean elasticity of substitution is between 6 and 11. These studies suggest that trade flows may be more responsive to permanent price movements than to temporary ones. Yi (2003), however, argues that the standard trade models fail to explain the 
growth in trade without assuming a counterfactually large cross-country substitutability, and that vertical integration partly explains the growth in trade. This suggests that estimates of cross-country substitutability from trade liberalization episodes are likely to be unrealistically high.

Our baseline choice for cross-country substitutability is 2 . This value is in line with empirical (short-term) estimates and used in the international macroeconomics literature (e.g. in Obstfeld and Rogoff 2007). We analyze the sensitivity of our main results as we vary cross-country substitutability from 0.5 to 11 .

The choice of tariff rate also warrants a more detailed explanation. First, tariff rates vary greatly across countries. Second, recent empirical estimates of effective tariff rates are rare. According to the World Bank (2014), the average (most-favored-nation applied and trade-weighted) nominal tariff rate for all products in OECD countries was $2.9 \%$ (1.7\% for manufactured products) in 2012. The corresponding worldwide tariff rates were $4.0 \%$ and $3.4 \%$. Effective rates, however, can differ from nominal ones. Deardorff and Stern (1984) found that the effective tariff rate in the European Union after the Tokyo round was roughly $8 \%$, whereas the nominal rate was roughly $6 \%$. This suggests that effective tariff rates are higher than nominal ones. Accordingly, we set the initial tariff rate to $4 \%$ in our baseline parameterization, which is somewhat higher than the OECD average. We analyze the sensitivity of the main results, setting the initial tariff rate in the $2 \%$ to $6 \%$ range.

As noted earlier, the parameter governing the persistence of the change in tariff rate is set to one $(\varphi=1)$. This implies that the changes in the tariff rates are permanent. The parameter $\psi_{t}$, used to model shifts in the tariff rate, is set such that we always analyze reduction in the tariff rate of a one percentage point. In the baseline parameterization (the tariff rate is four percent), this implies a reduction in the tariff rate of $25 \%$.

The Frisch elasticity of labor supply $(v)$ is a key parameter of the model. There is absolutely no consensus value for it. In a survey, Chetty et al. (2013) argued that micro evidence suggests that in macro models the Frisch elasticity (on the intensive margin) should be set to 0.5 . Keane and Rogerson (2012) likewise surveyed the empirical literature and argued that the Frisch elasticity is in the range to 1 to 2 at the macro level. They also pointed out that it is typical to set the Frisch elasticity to this range in macro models. Our baseline value for $v$ is 1 . This value is near the middle of empirical estimates and is widely used in macro models. We, however, implement a sensitivity analysis to assess how responsive the main results are to changes in this parameter.

The parameters ( $\alpha$ and $\alpha^{*}$ ) governing (exogenous) home bias in consumption are set such that the import-to-GDP ratio is realistic. According to the World Bank (2014), the average importto-GDP ratio for OECD countries in 2003-2012 was 26\%, while the worldwide number was 
$28 \%$. We set $\alpha$ to 1.47 . In addition, we assume that the share of imports is identical in both countries, thus $\alpha^{*}=(1-n \alpha) / n=0.53$. Our baseline parameterization, together with the fact that prices $\left(p_{0}(z)\right.$ and $\left.p_{0}^{*}(z)\right)$ are normalized to 1 and the tariff rate is $4 \%$, implies that the initial import-to-output ratio is $25 \%$. This roughly matches the OECD average. This value is quite commonly used in the international macroeconomics literature (e.g., in Obstfeld and Rogoff 2007). The import-to-GDP ratio is, however, much smaller in several countries. For example, in the United States the ratio averaged $16 \%$ in 2003-2012. We analyze the sensitivity of the main results, setting the import-to-GDP ratio in the $15 \%$ to $30 \%$ percent range. ${ }^{4}$

\section{EFFects of A UnILATERal TARIFF REduction}

In this section, we examine the consequences of unexpected, unilateral trade liberalization implemented by the domestic country. The domestic tariff rate is cut from $4 \%$ to $3 \%$ in period 1 . The international effects of a domestic tariff reduction appear in Figure 1. In all figures, the horizontal axes indicate time. The vertical axes typically show percentage deviations from the initial steady state. Changes in the bond holdings of domestic households (whose initial value is zero) are expressed as a deviation from initial consumption (Figure 1(f)). In addition, as discussed below, the value of trade liberalization (Figures 1(i) and 1(j)) is measured as a percentage of initial consumption.

The domestic terms of trade (ToT), shown in Figure 1(g), are defined as the relative producer price of domestic exports in terms of imports. The domestic terms of trade deteriorates if the index falls. The change in the terms of trade is given by

$\hat{T}_{o} T_{t}+=\hat{b}_{t}(z)-\hat{E}_{t}-\hat{b}_{t}^{*}(z)$,

where $\hat{b}_{t}(z)$ and $\hat{b}_{t}^{*}(z)$ are the Calvo-weighted prices of domestic and foreign goods (excluding tariffs), respectively, which can be expressed as

$\hat{b}_{t}(z)=\gamma \hat{b}_{t-1}(z)+(1-\gamma) \hat{p}_{t}^{h}(z)$

and

$\hat{b}_{t}^{*}(z)=\gamma \hat{b}_{t-1}^{*}(z)+(1-\gamma) \hat{p}_{t}^{* f}(z)$.

\footnotetext{
${ }^{4}$ We use the method of Klein (2000) and McCallum (2001) to simulate the model used here.
} 
Figure 1. Effects of a Unilateral Domestic Tariff Reduction
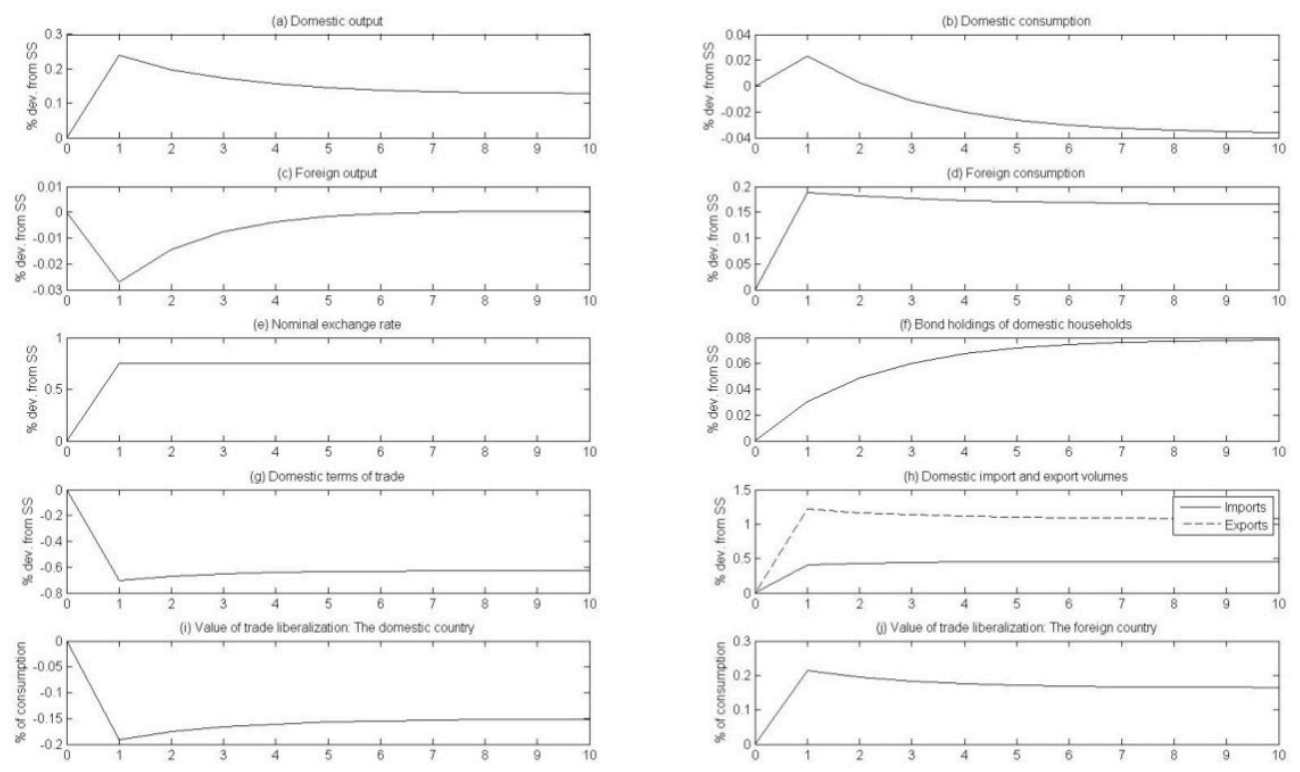

We adopt the view of Bagwell and Staiger (1999) that countries consider a trade agreement beneficial if it offers them greater welfare than they would enjoy without it. A trade agreement is therefore potentially beneficial only if unilateral trade policies lead to an inefficient equilibrium. The idea of a trade agreement is to remove inefficiencies that exist under unilateral trade policy so that countries can enjoy greater welfare.

Following Schmitt-Grohe and Uribe (2007), it is common-in macroeconomics - to evaluate the welfare cost of policy A relative to that of policy B by expressing the welfare difference as a percentage of consumption that households are willing to give up in order to be equally well off under policy A as under policy B. In this paper, we analyze the welfare benefit of a tariff reduction relative to a case with no tariff reduction. We measure the welfare benefit as a percentage of consumption that the household is willing to pay for a tariff reduction in order to render the household indifferent to the two cases. Reitz and Slopek (2005) find that imposing a tariff raises domestic welfare in the short term, but the long term effect is ambiguous. The finding that tariffs may affect welfare differently in the short term than in the long term compels us to study both the discounted present value (DPV) of trade liberalization and the evolution of welfare over time. 
Welfare in the case with "no tariff reduction" (NTR) in period $\mathrm{t}$ is denoted by $U_{t}^{N T R}$, and let $C_{s}^{N T R}, l_{s}^{\text {NTR }}(z)$ be the associated consumption and labor supply: ${ }^{5}$

$U_{t}^{N T R}=\sum_{s=t}^{\infty} \beta^{s-t}\left[\log C_{s}^{N T R}-\frac{\left(l_{s}^{N T R}(z)\right)^{1+1 / v}}{1+1 / v}\right]$.

The welfare benefit of a tariff reduction (TR) relative to the "no tariff reduction" case in period $\mathrm{t}$, holding labor supply constant, is defined as $\lambda_{t}$. Welfare in the "tariff reduction" case in period $\mathrm{t}$ is denoted by $U_{t}^{T R}$. With $\lambda_{t}$, it can be expressed as

$$
\begin{aligned}
U_{t}^{T R} & =\sum_{s=t}^{\infty} \beta^{s-t}\left[\log \left(1+\lambda_{t}\right) C_{s}^{N T R}-\frac{\left(l_{s}^{N T R}(z)\right)^{1+1 / v}}{1+1 / v}\right], \\
U_{t}^{T R} & =\frac{1}{1-\beta} \log \left(1+\lambda_{t}\right)+U_{t}^{N T R} .
\end{aligned}
$$

We express the welfare benefit of a tariff reduction as a percentage (rather than as a fraction) of consumption. Solving for $\lambda_{t}$ yields

$$
\lambda_{D P V}=100 \times\left[\exp (1-\beta)\left(U_{t}^{T R}-U_{t}^{N T R}\right)-1\right]
$$

A first-order Taylor expansion of the utility function implies that the change in utility in period $\mathrm{t}$ is given $b^{6}$

$$
d U_{t}=U_{t}-U_{0}=\left(\hat{C}_{t}-l_{0}^{1+1 / v} \hat{l}_{t}\right)
$$

The welfare level realized in the model is the one with a tariff reduction $\left(U_{t}^{T R}=U_{t}\right)$. In the case where the tariff rate remains constant, welfare in every period would remain at the initial level, implying that $U_{t}^{N T R}=U_{0}$. Using equation (30), equation (29) can be expressed as:

\footnotetext{
${ }^{5}$ We motivate the demand for money using the money-in-the-utility function approach. As usual in the macro literature, however, we focus the welfare analysis on the real component of the utility function, ignoring the welfare effect of money balances. The derivation of the welfare results follows that of Tervala (2012).

${ }^{6}$ We use a first-order approximation of the utility function, whereas several authors who have used the method of Schmitt-Grohe and Uribe (2007) has focused on stabilization policy using stochastic models, implying that one should take into account the volatility of consumption and the labor supply. We focus on a policy which aims to increase consumption and the labor supply and solve the model around a perfect-foresight path.
} 
$\lambda_{t}=100 \times\left[\exp (1-\beta)\left(\hat{C}_{t}-l_{0}^{1+1 / v} \hat{l}_{t}\right)-1\right]$

Equation (31) measures the percentage of initial consumption that the household is willing to pay for a tariff reduction in period $t$. This is referred to as the value of trade liberalization in the figures. Figure 1(i) shows that the value of a tariff reduction is negative for the home country, implying that domestic households are willing to bear a cost to avoid trade liberalization in all periods.

The overall welfare effect is more important than the effect on one period's welfare. The next step is to calculate the DPV of the welfare benefit of tariff reduction. The DPV of welfare in the "no tariff reduction" case is denoted by $U_{D P V}^{N T R}$ and $\left\{C_{s}^{N T R}, l_{s}^{N T R}(z)\right\}_{s=t}^{\infty}$ is the associated consumption and labor supply paths:

$U_{D P V}^{N T R}=\sum_{s=t}^{\infty} \beta^{s-t}\left[\log C_{s}^{N T R}-\frac{\left(l_{s}^{N T R}(z)\right)^{1+1 / v}}{1+1 / v}\right]$.

Welfare in the "tariff reduction" case is denoted by $U_{D P V}^{T R}$ The DPV of the welfare benefit of a tariff reduction relative to the "no tariff reduction" case is denoted by $\lambda_{D P V}$. With this definition, welfare in the event of a tariff reduction, denoted by $U_{D P V}^{T R}$, can be expressed as

$U_{D P V}^{T R}=\frac{1}{1-\beta} \log \left(1+\lambda_{D P V}\right)+U_{D P V}^{N T R}$

Expressing the welfare benefit of a tariff reduction as a percentage of consumption and solving for $\lambda_{D P V}$ yields

$$
\lambda_{D P V}=100 \times\left[\exp (1-\beta)\left(U_{D P V}^{T R}-U_{D P V}^{N T R}\right)-1\right]
$$

Following the same steps as those in the one-period case and using the DPV of the change in utility, equation (33) can be written as

$$
\lambda_{D P V}=100 \times\left[\exp (1-\beta)\left(\sum_{s=t}^{\infty} \beta^{s-t}\left(\hat{C}_{s}-l_{0}^{1+1 / v} \hat{l}_{s}\right)\right)-1\right]
$$

Equation (34) measures the DPV of the welfare gain of a trade agreement as a percentage of initial consumption. This measures the welfare benefit as a percentage of consumption that the household is willing to pay for a tariff reduction in order to render the household indifferent to 
the two cases. The value of trade liberalization worldwide measures the population-weighted average of the value of a tariff reduction

$\lambda_{D P V}^{W}=n \lambda_{D P V}+(1-n) \lambda_{D P V}^{*}$.

In equation (35), superscript $\mathrm{W}$ denotes the world.

Figure 1(a) shows that domestic trade liberalization increases output in the home country: in the first period output increases $0.24 \%$ while the long term effect is $0.13 \%$. A domestic tariff reduction implies a smaller distortionary effect on the labor supply (recall equations (11) and (12)). A tariff reduction therefore increases domestic output, a finding that is consistent with those of Fender and Yip (2000) and Reitz and Slopek (2005), who find that imposing of a tariff decreases output.

In his survey of the empirical literature on the relationship between international trade and economic performance, Singh (2010) concluded that the macroeconomic evidence clearly supports positive and significant effects of trade on output. Our model is consistent with this finding, as trade liberalization leads to more trade and higher output. It can be argued, however, that this empirical literature tells us little about the effects of trade policy on output, as discussed in Dollar and Kraay (2004). Their study of the consequences of changes in trade policy found that trade liberalization is strongly correlated with changes in economic growth. Our results are consistent with this finding, in so far as trade liberalization increases the level of output. In their survey of the evidence on the empirical effects of tariff reductions on employment (in developing countries), Cirera et al. (2013) found that, when openness indicators (a share of exports, imports or both, over GDP) are used as the trade policy proxy, more openness is associated with higher employment.

Figure 1(i) indicates that the value of trade liberalization is negative for the home country. Domestic households are willing to pay part of their consumption to avoid trade liberalization despite an increase in output. In the model with imperfectly competitive economies and distortionary taxes, the levels of output and consumption are suboptimally low. Thus, a tariff reduction could increase these levels (of output and consumption) and bring them closer to the social optimum, thereby enhancing welfare. The deterioration in the domestic terms of trade, however, implies that trade liberalization increases in output with no equivalent increase in consumption. The value of unilateral trade liberalization is therefore negative.

The domestic terms of trade deteriorate for two reasons. First, by reducing tariffs, the home country increases the worldwide demand for the goods that it imports. Therefore, trade liberalization increases the price of the home country's imports. Second, an increase in the supply of domestic goods lowers their relative price. 
As Figure 1(e) shows, the exchange rate depreciates $(0.75 \%)$. The domestic terms of trade deterioration decrease (increase) in domestic (foreign) consumption. Therefore, the relative demand for domestic money weakens, causing a depreciation in the exchange rate. In addition, equation (13) shows that a domestic tariff reduction has a positive effect on the real domestic money supply. A lower tariff implies lower domestic prices, which increase the relative real money supply, which in turn reinforces the depreciation of the domestic currency. Depreciation in the exchange rate leads to an expenditure switching effect. Domestic goods become cheaper, and demand for them temporarily increases. This explains the temporary increase (decrease) in domestic (foreign) output relative to the new steady state. In the short term, in an effort to smooth consumption, domestic households save part of their income by running a (small) current account surplus. The surplus is reflected in the increase in the bond holdings (see Figure $1(\mathrm{f})$.

There is almost no empirical evidence on the current account effects of trade liberalization. In a rare paper, Ju et al. (2012) used data on 28 episodes to determine that trade liberalization on average improves the current account (if liberalization reduces the capital intensity of the economy). For example, China's trade liberalization (including accession to the WTO) in the beginning of the 2000s was associated with an improvement in the current account.

The DPV of the welfare benefit of a tariff reduction is negative for the home country due to a fall in consumption resulting from a deterioration in the terms of trade. In addition, the DPV of the welfare benefit of trade liberalization for the foreign country and the world is positive: the foreign country and the world as a whole benefit from domestic trade liberalization. Our findings are directly related to the optimal tariff argument: a large country can improve its terms of trade by imposing a tariff, even if this reduces worldwide welfare.

Fender and Yip (2000) found that, under flexible prices, imposing a permanent tariff most likely increases domestic steady-state utility. A sufficient condition for a positive welfare effect is that the elasticity of substitution between differentiated goods (equal to the price elasticity of demand) is greater than the intertemporal elasticity of consumption. According to Svensson and van Wijnbergen (1989), this implies that domestic and foreign goods are Edgeworth-Pareto complements. The assumption that the intertemporal elasticity of consumption is one would render the model compatible with a balanced growth path if trend technological progress was introduced into the model (see King, Plosser and Rebelo 1988). In addition, in the framework of Fender and Yip (2000), the elasticity of substitution between differentiated goods must be greater than one in order to make the demand slope downward. Therefore, Fender and Yip (2000) in essence found that a tariff increases domestic welfare. In addition, they found that domestic tariffs reduce foreign and worldwide welfare. Our results are consistent with these findings. 
Reitz and Slopek (2005) extended by the model of Fender and Yip (2000) with the current account adjustment and found that the short-term effect of the imposition of a tariff on welfare is positive, but the long-term effect is ambiguous. They also find that the DPV of the welfare effect is positive for the home country and negative for the foreign country and the world. The authors find that tariffs create a short-term current account deficit and that the need to pay interest rates abroad in the long term dampens the welfare benefit of improving the terms of trade. However, under no plausible parameter combinations do they show that the long-term welfare effect of imposing a tariff would be negative. In our model, the long-term welfare loss from the deterioration of the terms of trade dominates the long-term welfare benefits of extra consumption that the accumulated wealth can generate. ${ }^{7}$

The international economics literature has shown that results can be sensitive to the value of cross-country substitutability, so we analyzed whether changes in cross-country substitutability would affect the value of trade liberalization. As discussed in Section 3, we varied cross-country substitutability from 0.5 to 11 . In addition, we varied the initial tariff rate from $2 \%$ to $4 \%$. The value of trade liberalization turned out to be negative (positive) for the home (foreign) country for all parameter combinations. In addition, when domestic and foreign goods are EdgeworthPareto substitutes $(\rho>1)^{8}$, changes in the initial tariff level and cross-country substitutability have a minor quantitative impact on the value of a tariff reduction.

As discussed earlier, the main finding of Fender and Yip (2000) is that a sufficient condition for a positive welfare effect from imposing of a tariff is that the elasticity of substitution between differentiated goods is greater than the intertemporal elasticity of consumption. We found that, using a framework in which cross-country substitutability can differ from within-country substitutability and even when domestic and foreign goods are Edgeworth-Pareto complements, the value of a tariff reduction is negative for the home country. Moreover, we found that the value of trade liberalization in such a case is more negative than under the baseline parameterization. A deterioration in the domestic terms of trade implies that consumption declines. When domestic and foreign goods are complements, domestic households do not shift consumption from domestic goods to foreign goods, but reduce their consumption of both domestic and foreign goods. Aggregate consumption thus falls by more than when domestic and

\footnotetext{
${ }^{7}$ Hwang and Turnovsky (2013) analyze the macroeconomic effects of tariffs using an open-economy model and find that the short-term effects of unanticipated tariffs on welfare depend on the currency of export pricing, the monetary policy rule, the share of non-traded goods in the consumption basket and the share of exports in total production. However, they do not show that even the short-term welfare effect of an increase in tariff would be negative under plausible parameter combinations.

${ }^{8}$ The assumption of $\log$ utility implies that the intertemporal elasticity of consumption is one. Therefore, domestic and foreign goods are Edgeworth-Pareto substitutes (complements) in our model when $\rho>1(\rho<1)$.
} 
foreign goods are Edgeworth-Pareto substitutes. Consequently, the value of trade liberalization for a domestic (foreign) country is more negative (positive) than under the baseline case.

As usual in the international economics literature, the current account response depends on whether the Marshall-Lerner condition is satisfied (in the current framework, this requires that $\rho$ $>1$ ). The assumption of $\rho=0.5$ therefore reverses the behavior of the current account, and trade liberalization brings about a current account deficit. This, however, does not affect the DPV of a tariff reduction, because current account imbalances optimally smooth over household consumption.

The main conclusion of this section, that the value of a domestic tariff reduction is negative for the home country and positive for the foreign country and the world, is a robust finding. In our model, therefore, the two countries have no incentive to implement unilateral trade liberalization.

\section{VAlue of WTO Trade Agreements}

This section analyzes the main theme of the paper-the value of WTO trade agreements. One of the main objectives of the WTO is reciprocal trade liberalization. In this paper, we use the term reciprocity with the same meaning as defined in Bagwell and Staiger (2002): "[M]utual adjustments in trade policy conform to the principle of reciprocity if these policy adjustments bring about changes in the volume of each country's imports that are of equal value to changes in the volume of its exports." (Bagwell and Staiger 2002, 6).

It is useful to make a distinction between bound and applied tariff rates. According to the WTO (2014), "bound rates are the ceiling rates as listed in members' "schedules" or lists of commitments", whereas "applied rates are the rates members currently charge, which can be lower than the bound rates". In this section, we analyze the international effects of a WTO agreement which leads to a one percentage point reduction in the applied tariff rate in both countries, i.e., the tariff rate is reduced from $4 \%$ to $3 \%$ in the both countries. This satisfies the principle of reciprocity: trade liberalization causes equal changes in export and import volumes in the both countries.

The effects of this exercise appear in Figure 2 and Table 2. Figure 2 shows that because countries and shocks are identical, multilateral trade liberalization increases domestic and foreign output by the same amount. ${ }^{9}$ Output increases by $0.21 \%$ in the first period and $0.13 \%$ in the long term. As discussed in Section 4, a tariff reduction reduces tax distortions on the labor supply. The fact that output increases more in the short term than in the long term is caused by

\footnotetext{
${ }^{9}$ The only asymmetry in the model is that the bond is denominated in the domestic currency. This does matter because the nominal interest rate is identical in both countries.
} 
changes in the real wage. In the long term, prices are higher due to an increase in output. In the short term, only a fraction of firms are able to raise their prices. Consequently, real wages are temporarily high in the short term, creating a stronger incentive to work.

Figure 2. Effects of Reciprocal Trade Liberalization
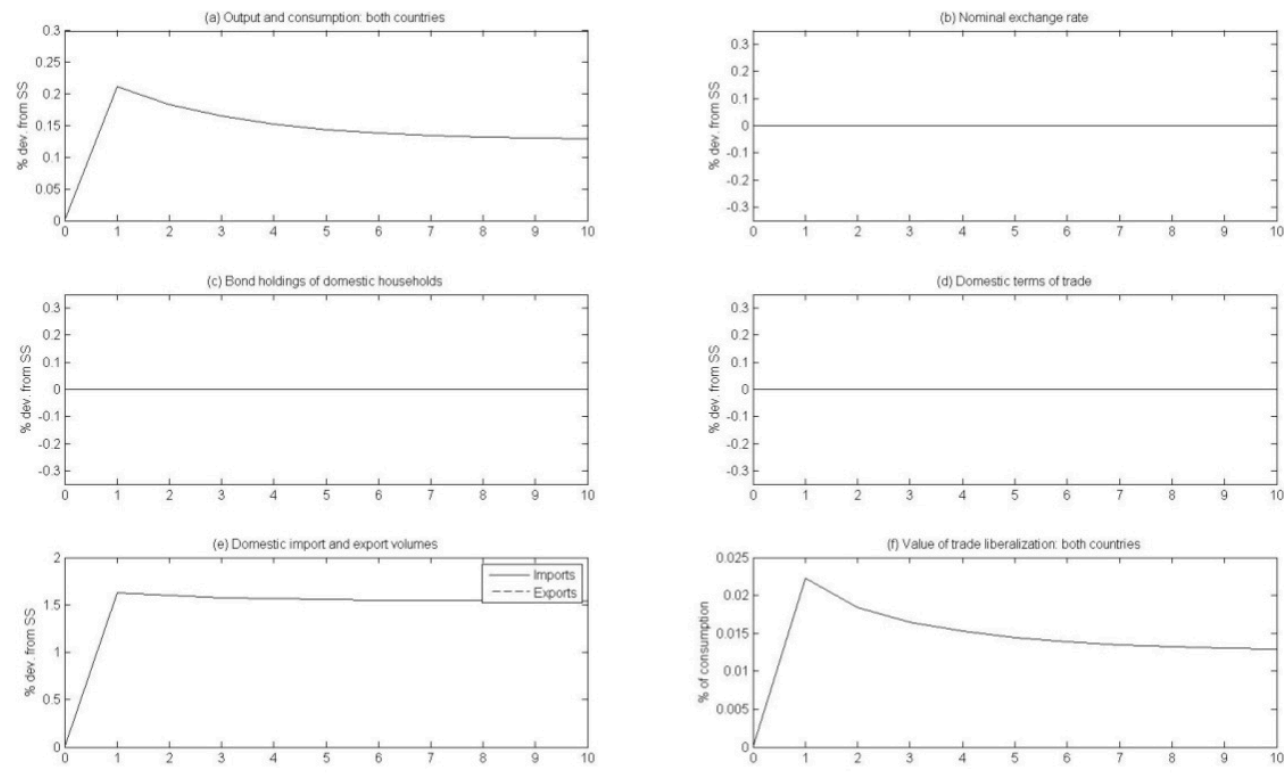

Reciprocal trade liberalization, together with the fact that the countries are identical, implies that the responses of output and consumption are identical across countries. Identical changes in the supply and demand for goods in both countries imply that the terms of trade remain constant. In addition, the exchange rate also remains constant, because changes in the demand and supply for (real) money are identical across countries.

Figure 2(f) shows that domestic and foreign households are willing to pay $0.02 \%$ of their initial consumption for a tariff reduction in the first period. This figure shows that reciprocal trade liberalization benefits both countries. Table 2 shows the DPV of a trade agreement. ${ }^{10}$ In an imperfectly competitive economy, an increase in output, which causes an identical increase in consumption, brings both consumption and output closer to their efficient levels, thereby increasing welfare. If a country implements a unilateral tariff reduction, it experiences a deterioration in its terms of trade, as discussed earlier. This reduces welfare, despite an increase in output. Nevertheless, countries have an incentive for multilateral trade liberalization. A multilateral tariff reduction brings output and consumption closer to their efficient levels, such that a deterioration in the terms of trade does not offset the benefits of higher output. A WTO

\footnotetext{
${ }^{10}$ We calculate the DPV using 1,000 periods.
} 
trade agreement, therefore, offers countries a means to escape from the prisoner's dilemma, driven by manipulation of the terms of trade. Table 2 shows that, under the baseline parameterization, domestic and foreign households would be willing to pay $1.3 \%$ of their initial consumption for a trade agreement, in order to remain as well off with the trade agreement case as without it. This means that WTO trade agreements are valuable. The policy implication is that completion of the Doha Round should be a high priority.

Table 2. DPV of a WTO Trade Agreement as the Percentage of Consumption

\begin{tabular}{|c|c|c|c|}
\hline & \multicolumn{3}{|c|}{ Initial tariff rate } \\
\hline $\begin{array}{c}\text { Cross-country } \\
\text { substitutability }\end{array}$ & 2 & 4 (baseline) & 6 \\
\hline$\rho=0.5$ & 1.3 & 1.3 & 1.3 \\
\hline$\rho=1.1$ & 1.3 & 1.3 & 1.3 \\
\hline$\rho=2$ (baseline) & 1.3 & 1.3 & 1.3 \\
\hline$\rho=5$ & 1.3 & 1.3 & 1.3 \\
\hline$\rho=11$ & 1.3 & 1.3 & 1.3 \\
\hline
\end{tabular}

As mentioned in Section 3, the main results are potentially sensitive to the value of crosscountry substitutability. However, Table 2 shows that it has (virtually) no impact on the value of a trade agreement. In addition, the effect of the initial tariff level on the value of a trade agreement is negligible.

Next, we analyze the role of the degree of openness. Table 3 shows that the value of a trade agreement is sensitive to changes in the import-to-GDP ratio. When the import-to-GDP ratio is $15 \%$, the welfare gain from a trade agreement is $0.76 \%$ of initial consumption. The smaller the import-to-GDP ratio is, the smaller the welfare gains from a trade agreement.

Table 3. Import-to-GDP Ratio and the Value of a WTO Trade Agreement

\begin{tabular}{|c|c|c|c|c|}
\hline $\begin{array}{c}\text { Import-to-GDP } \\
\text { Ratio }\end{array}$ & $15 \%$ & $20 \%$ & $\begin{array}{c}25 \% \\
\text { (baseline) }\end{array}$ & $30 \%$ \\
\hline $\begin{array}{c}\text { Value of an } \\
\text { Agreement }\end{array}$ & 0.76 & 1.0 & 1.3 & 1.6 \\
\hline
\end{tabular}

Eaton and Kortum (2002) developed a new trade model that can convincingly quantify the welfare gains of unilateral and multilateral trade liberalization. They calibrated the multicountry model with data from 19 OECD countries for the year 1990. For example, the tariff rate was set to $5 \%$, based on the OECD average at that time. Eaton and Kortum found that a unilateral tariff removal by the United States causes a welfare loss in that country, due a deterioration of the terms of trade, while all other countries benefit. The multilateral elimination 
of tariffs improves welfare. Eaton and Kortum did not show their results for all countries, but they mentioned that (in case of immobile labor) the welfare gains never exceed $0.5 \%$.

Caliendo and Parro (2015) developed a multi-country, multi-sector Ricardian model to explore quantitatively the welfare effects of tariff reductions caused by NAFTA. They found that NAFTA has increased Mexico's welfare by a range of $1.17 \%$ to $1.31 \%$ and the United States' welfare by $0.08 \%$, whereas Canada's welfare has declined by $0.06 \%$.

Ossa (2011) developed the relocation theory of the WTO, using a new trade model in which firms produce differentiated goods that they can sell on the domestic and foreign market. In this model, entry is free and exporting is costly. If the home country imposes a tariff, foreign firms relocate to the home country. This relocation implies that domestic households save trade costs and local prices drop, which increases domestic welfare. Foreign welfare decreases as local prices increase due to trade costs. Policy makers maximize welfare that depends solely on consumption. This leads them to maximize the number of domestic manufacturing firms (jobs). Ossa found that reciprocity can be interpreted as simple rules that help countries to neutralize the production relocation effect. Using a multi-country model, he found that reciprocal trade liberalization, under which countries implement tariff changes that maximize the mean welfare change, led to a mean welfare gain of just $0.09 \%$ to $0.11 \%$. This finding led Ossa (2011) to conclude that the gains from WTO negotiations are moderate.

Ossa (2014) quantitatively analyzed non-cooperative and cooperative trade policy in a framework that featured the terms of trade effect, the production relocation effect and the political economy effect. He calibrated the multi-country, multi-industry general equilibrium model to match the features of seven countries and regions (Brazil, China, the European Union, India, Japan, the United States and the rest of the world), chosen to comprise the main players in WTO negotiations, in the year 2007. He found that in the cases where initial tariff rates were set to match factual rates, the average welfare gain of a WTO trade agreement was $0.5 \%$.

Our main results contrast sharply with the above-mentioned trade literature. Eaton and Kortum (2002), Caliendo and Parro (2015) and Ossa (2011 and 2014) found that a trade agreement that leads to the elimination (or a notable reduction) of tariffs yields smaller welfare improvements. In our model, the welfare gain of a trade agreement, which reduces tariffs by just one percentage point, is $0.76 \%$ to $1.6 \%$ of consumption (see Table 2). An elimination of tariffs would lead to even greater welfare gains. The gains of WTO agreements are therefore substantial.

Several potential reasons may explain the substantial difference in the main results. The first is the method of welfare analysis. We calculated consumption compensation necessary for households to be as well off in the trade agreement case as without it, whereas Eaton and 
Kortum (2002), Caliendo and Parro (2015) and Ossa (2011 and 2014) calculated change in welfare. The method, however, cannot explain the differences, because in our model the DPV of a change in utility (in percentages) is almost the same as the DPV of the welfare gain in terms of initial consumption.

The second potential explanation is the degree of openness. We set the import-to-GDP to match the OECD average in 2003-2012. Eaton and Kortum (2002), for example, used bilateral data of manufacturing trade between 19 OECD countries in 1990, when the import-to-GDP ratio in the OECD countries was $18 \%$. The degree of openness, however, cannot account for the difference. As mentioned earlier, Eaton and Kortum (2002) found that multilateral elimination of the initial tariff of $5 \%$ causes welfare gains that never exceed $0.5 \%$. In our model, when the import-toGDP ratio is $15 \%$, the welfare gain of the multilateral elimination of the initial tariffs of $5 \%$ is as high as $3.8 \%$ of consumption.

One innovation of our model, relative to the existing models that have been used in the literature on trade agreements, is to introduce transitional dynamics with the introduction of staggered price setting. This is the third potential explanation for the difference in the main results. With flexible prices, the economies would jump instantly to the new steady state. Figure 2(e) shows that the value of a trade agreement is higher in the short term than in the long term. Therefore, the introduction of staggered price setting increases the DPV of a trade agreement. As discussed earlier, real wages are temporarily high in the short term, creating a stronger incentive to work. This brings the economy in the short term closer to the efficient level of output, thus increasing welfare, relative to the new steady state.

Staggered price setting, however, cannot account for the differences in the results. In an alternative scenario, we set the price rigidity parameter to zero, implying that prices are fully flexible. This reduces the DPV of a trade agreement to $1.28 \%$, while the value is $1.31 \%$ under the baseline parameterization.

Another main innovation of this model, relative to the existing models in the literature on trade agreements, is to change the underlying steady state of the trade models by introducing a different market structure from the one usually assumed. The fourth potential explanation is therefore the presence of imperfect substitutability between goods within the same country/industry. On one hand, Table 2 shows that the value of a trade agreement is (virtually) the same if cross-country substitutability equals within-country substitutability. On the other hand, the degree of imperfect competition within the country/industry (within-country substitutability) has an effect on the initial level of output: The lower within-country substitutability is, the lower the initial level of output. As mentioned in Section 3, withincountry substitutability does not influence the response of endogenous variables. However, the lower within-country substitutability is, the more an identical increase in output and 
consumption (of given size) increases welfare. Therefore, the welfare gains of trade liberalization depend on the degree of within-country substitutability.

Within-country substitutability-in quantitative macroeconomics - is virtually always set between 6 and 20, implying a price markup of 20\% and 5\%, respectively. However, Eaton and Kortum (2002), Caliendo and Parro (2015) and Ossa (2011 and 2014) assume perfect competition within the industry, implying that within-country substitutability is very high. When within-country substitutability gets larger and goods produced in the same country become close substitutes, the producers' monopoly power declines. We also look at the limiting case of almost perfect competition, by checking the implications of setting within-country substitutability to the value of 100 , implying a low price markup of roughly $1 \%$.

Table 4 demonstrates the dependence of the value of a trade agreement on within-country substitutability and the Frisch elasticity of labor supply. Row 3 of Table 4 shows the consequences of varying within-country substitutability, holding the Frisch elasticity of labor supply at 1 . The benefit of a trade agreement is significantly reduced when goods produced in the same country become close substitutes $(\theta=100)$. The welfare gain then falls to $0.26 \%$ of consumption. This is one-fifth of the gain under the baseline parameterization. In any case, the quantitative difference between our results and those of Eaton and Kortum (2002), Caliendo and Parro (2015) and Ossa (2011 and 2014) is striking.

Table 4. Sensitivity Analysis: The Role of Within-Country Substitutability and the Frisch Elasticity of Labor Supply

\begin{tabular}{|c|c|c|c|c|c|}
\hline Row & $\theta=6$ & $\begin{array}{c}\theta=11 \\
\text { (baseline) }\end{array}$ & $\theta=20$ & $\theta=100$ \\
\hline 1 & $v=0.1$ & 0.43 & 0.25 & 0.15 & 0.050 \\
\hline 2 & $v=0.5$ & 1.5 & 0.88 & 0.52 & 0.18 \\
\hline 3 & $\begin{array}{c}v=1 \\
\text { (baseline) }\end{array}$ & 2.3 & 1.3 & 0.78 & 0.26 \\
\hline 4 & $v=2$ & 3.1 & 1.7 & 1.0 & 0.35 \\
\hline
\end{tabular}

The public economics literature has shown that optimal taxation depends notably on the effects of taxation on aggregate labor supply. Trade models that have been used to analyze the gains of multilateral tariff reductions, however, typically assume that household labor supply is exogenous. In those models, the utility function depends solely on consumption. A distinctive feature of our model is the endogeneity of labor supply. Therefore, we analyze how sensitive the main results are to changes in the Frisch elasticity of labor supply. As mentioned in Section 3, Keane and Rogerson (2012) argued that the Frisch elasticity could be as high as 2, whereas Chetty et al. (2013) argued that it should be set to 0.5 . We use this range in the sensitivity 
analysis. In addition, we set the Frisch elasticity to 0.1 to discuss the implications of the endogeneity of labor supply to the value of trade agreements.

Table 4 shows that the higher the Frisch elasticity is, the larger the welfare gains of a trade agreement. This is because with higher elasticity of labor supply households respond to a tariff cut by further increasing their labor supply. This brings consumption and output of an imperfectly competitive economy closer to their efficient levels, thereby increasing welfare. If the Frisch elasticity is 0.5 (2), the value of a trade agreement drops (increases) to $0.88 \%(1.7 \%)$ of initial consumption, when within-country substitutability is 11 . The welfare gain seems implausibly high (3.1\% of consumption) when within-country substitutability is 6 and the Frisch elasticity is 2. We would like to stress in this connection than the consensus among economists - in particular among labor economists - is that the Frisch elasticity is smaller than 2. Table 4 shows that for the realistic parameter combinations of the Frisch elasticity of labor supply and within-country substitutability, the value of the welfare gain of a trade agreement, which cuts tariffs by one percentage point, is $0.5 \%$ to $2 \%$ of initial consumption.

Our main results contrast sharply with those of Eaton and Kortum (2002), Caliendo and Parro (2015) and Ossa (2011 and 2014) as long as the Frisch elasticity and within-country substitutability are within the range of empirical estimates. However, our results are consistent with earlier studies, in cases where the Frisch elasticity is very low $(v=0.1)$ and withincountry substitutability ( $\theta=20$ or 100 ) is high. In these cases, reciprocal trade liberalization that eliminates $4 \%$ tariffs induces welfare gains of $0.2 \%$ to $0.6 \%$ of initial consumption. In comparison, Eaton and Kortum (2002) found that the multilateral elimination of 5\% tariffs yields welfare gains that never exceed $0.5 \%$. Caliendo and Parro (2015) discovered that the welfare effects of tariff reductions caused by NAFTA are on average $0.42 \%$. Ossa (2014) found that the average welfare gain of a trade agreement that eliminates factual tariffs is $0.5 \%$.

The main source of the differences between our results and those Eaton and Kortum (2002), Caliendo and Parro (2015) and Ossa (2014) on the benefits of multilateral trade liberalization is the combination of the degree of within-country substitutability and the magnitude of the labor supply response to a tariff reduction. Our results suggest that for the realistic parameter combinations of the Frisch elasticity of labor supply and within-country substitutability, the welfare gains of trade agreements are much larger than in recent trade models.

\section{Conclusions}

This paper quantifies the welfare effects of unilateral and multilateral tariff reductions in a twocounty model that combines Armington and New Keynesian elements. The Armington element, in which international trade takes place because goods are differentiated by the country of

origin, is familiar in models that have been used in the literature on trade agreements. Staggered 
price adjustment, endogenous labor supply and the presence of imperfect substitutability between goods produced within the country are the most important features of the model.

We set the parameters of the model to reflect existing tariff rates and import-to-GDP ratios in the OECD countries in order to derive the main results. Our findings show that the value of a WTO trade agreement depends significantly on within-country substitutability and the Frisch elasticity of labor supply. Our view is that for realistic parameter combinations, the value of the welfare gain of a trade agreement, which cuts tariffs by one percentage point, is $0.5 \%$ to $2 \%$ of initial consumption. Our main results contrast sharply with Eaton and Kortum (2002), Caliendo and Parro (2015) and Ossa (2014), who find that multilateral trade liberalization yields considerably smaller welfare gains. We conclude that WTO trade agreements are of high value, with the implication that completion of the Doha Round should be a high priority. 


\section{REFERENCES}

Bagwell, K. and R. W. Staiger, 1999. An economic theory of GATT. American Economic Review 89, 215-248.

Bagwell, K. and R. W. Staiger, 2002. The Economics of the World Trading System. Cambridge, MA: MIT Press.

Bagwell, K. and R. W. Staiger, 2011. What do trade negotiators negotiate about? American Economic Review 101, 1238-1273.

Basu, S. and J. G. Fernald, 1997. Returns to scale in U.S. production: Estimates and implications. Journal of Political Economy 105, 249-283.

Bergin, P. R, 2006. How well can the new open economy macroeconomics explain the exchange rate and current account? Journal of International Money and Finance 25, $675-701$.

Broda, C., N. Limão and D. E. Weinstein, 2008. Optimal tariffs and market power: The evidence. American Economic Review 98, 2032-2065.

Caliendo, L. and F. Parro, 2015. Estimates of the trade and welfare effects of NAFTA. Review of Economic Studies 82, 1-44.

Calvo, G. A., 1983. Staggered prices in a utility maximizing framework. Journal of Monetary Economics 12, 383-398.

Chetty, R., A. Guren, D. Manoli and A. Weber, 2013. Does indivisible labor explain the difference between micro and macro elasticities? A meta-analysis of extensive margin elasticities. NBER Macroeconomics Annual 2012 27, 1-56.

Cirera, X., D. Willenbockel and R. W.D. Lakshman, 2013. Evidence on the impact of tariff reductions on employment in developing countries. Journal of Economic Surveys 28, 449-471.

Deardorff, A. V. and R. M. Stern, 1984. The effects of the Tokyo round on the structure of protection in The Structure and Evolution of Recent U.S. Trade Policy, Robert E. Baldwin and Anne O. Krueger, editors. University of Chicago Press, Chicago

Dollar, D. and A. Kraay, 2004. Trade, growth, and poverty. Economic Journal 114, F22-F49. 
Eaton, J. and S. Kortum, 2002. Technology, geography, and trade. Econometrica 70, 17411779.

Feenstra, R., P. Luck, M. Obstfeld and K. Russ, 2014. In search of the Armington elasticity. NBER Working Paper 20063.

Fender, J. and C. K. Yip, 2000. Tariffs and exchange rate dynamics redux. Journal of International Money and Finance 19, 633-655.

Gopinath, G. and R. Rigobon, 2008. Sticky borders. Quarterly Journal of Economics 123, 531575.

Hwang, Y-N. and S. J. Turnovsky, 2013. Exchange rate pass-through and the effects of tariffs on economic performance and welfare. Journal of International Money and Finance 33, $81-101$.

Head, K. and J. Ries, 2001. Increasing returns versus national product differentiation as an explanation for the pattern of U.S.-Canada trade. American Economic Review 91, 858876.

Hooper P., K. Johnson, and J. Marquez, 2000, Trade elasticities for the G-7 countries. Princeton Studies in International Economics. Princeton University, Princeton.

Johnson HG. 1953-1954. Optimum tariffs and retaliation. Review of Economic Studies 21, $142-153$.

Ju, J., K. Shi and S-J. Wei, 2012. Trade reforms and current account imbalances: When does the general equilibrium effect overturn a partial equilibrium intuition? NBER Working Paper 18653.

Keane, M. and R. Rogersson, 2012. Micro and macro labor supply elasticities: A reassessment of conventional wisdom. Journal of Economic Literature 50, 464-476.

King, R. G., C. Plosser and S. T. Rebelo, 1998. Production, growth and business cycles: I. The basic neoclassical model. Journal of Monetary Economics 21, 195-232.

Klein, P., 2000. Using the generalized Schur form to solve a multivariate linear rational expectations model. Journal of Economic Dynamics and Control 24, 1405-1223. 
Mankiw, N. G., and L. H. Summers, 1986. Money demand and the effects of fiscal policies. Journal of Money, Credit and Banking 18, 415-429.

McCallum, B., 2001, Software for RE analysis. Computer software available at http://wpweb2.tepper.cmu.edu/faculty/mccallum/research.html

Obstfeld, M. and K. Rogoff, 2007. The unsustainable U.S. current account position revisited" in R. H. Clarida (ed.) G7 Current Account Imbalances: Sustainability and Adjustment. University of Chicago Press, Chicago.

Ossa R. 2011. A “new trade” theory of GATT/WTO negotiations. Journal of Political Economy $119,122-152$.

Ossa R. 2014. Trade wars and trade talks with data. American Economic Review 104, 41044146.

Schmitt-Grohe, S and M. Uribe, 2007. Optimal dimple and implementable monetary and fiscal rules. Journal of Monetary Economics 54, 1702-1725.

Singh, T., 2010. Does international trade cause economic growth? A survey. World Economy $33,1517-1564$.

Svensson, L., van Wijnbergen, S., 1989. Excess capacity, monopolistic competition and international transmission of monetary disturbances. Economic Journal 99, 785-805.

Reitz, S. and U. D. Slopek, 2005. Macroeconomic effects of tariffs: Insights from a new open economy macroeconomics model. Swiss Journal of Economics and Statistic 141, 285311.

Romalis, J., 2007. NAFTA's and CUSFTA's impact on international trade. Review of Economics and Statistics 89: 416-435.

Tille, C., 2001. The role of consumption substitutability in the international transmission of monetary shocks. Journal of International Economics 53, 421-444.

Tervala, J., 2012. International welfare effects of monetary policy. Journal of International Money and Finance 31, 356-375.

Yi, K-M., 2003. Can vertical specialization explain the growth of world trade? Journal of Political Economy 111, 52-102. 
World Bank, 2014. Data available online at http://data.worldbank.org/ (accessed 30.9.2014).

WTO, 2014, "Tariffs" Available online at http://www.wto.org/english/tratop e/tariffs e/tariffs e.htm (accessed 24.1.2014). 